\title{
KINERJA PEMASARAN BERBASIS GENDER DIVERSITY
}

\author{
Ali \\ Fakultas Ekonomi dan Bisnis Universitas Islam Nahdlatul Ulama (UNISNU) Jepara \\ email: ali@unisnu.ac.id
}

\begin{abstract}
Marketing performance has a very important role in UKM Furniture in Jepara Regency. The purpose of this study is to analyze marketing performance based on gender diversity. The implication for managerial and policy as a basis for solving marketing performance problems is based on gender diversity. Methodology: product innovation, marketing innovation, competitive advantage and network access will play an important role to measure marketing performance based on gender diversity. Based on empirical studies gender diversity has an important role in company policy, especially related to marketing performance. Women's gender has an influence on marketing performance of 80,247 compared to men's gender only has an effect of 58,753. Limitations of the study: only examined 5 variables influencing factors: product innovation, marketing innovation, competitive advantage, network access and marketing performance. Practical implications: product innovation, marketing innovation, competitive advantage and network access will affect marketing performance based on gender diversity.
\end{abstract}

Keywords: marketing performance, product innovation, marketing innovation, competitive advantage and network access

\begin{abstract}
ABSTRAK
Kinerja pemasaran sangat penting peranannya di UKM Mebel Kabupaten Jepara. Tujuan dari penelitian ini adalah untuk menganalisis kinerja pemasaran berdasarkan gender diversity. Implikasinya terhadap manajerial dan kebijakan sebagai dasar penyelesaian masalah kinerja pemasaran berdasarkan perbedaan jenis kelamin (gender diversity). Metodologi: inovasi produk, inovasi pemasaran, keunggulan bersaing dan akses jaringan akan memainkan peran penting untuk mengukur kinerja pemasaran berdasarkan gender diversity. Berdasarkan studi empiris gender diversity mempunyai peran penting dalam kebijakan perusahaan terutama berhubungan dengan kinerja pemasaran. Gender wanita mempunyai pengaruh dalam kinerja pemasaran sebesar 80,247 dibanding gender pria hanya mempunyai pengaruh sebesar 58,753. Keterbatasan penelitian : hanya meneliti 5 variabel faktor yang mempengaruhi: inovasi produk, inovasi pemasaran, keunggulan bersaing, akses jaringan dan kinerja pemasaran. Implikasi praktis: inovasi produk, inovasi pemasaran, keunggulan bersaing dan akses jaringan akan berpengaruh terhadap kinerja pemasaran yang berbasis gender diversity.
\end{abstract}

Kata kunci: kinerja pemasaran, inovasi produk, inovasi pemasaran, keunggulan bersaing dan akses jaringan 


\section{PENDAHULUAN}

Perkembangan kinerja pemasaran UKM mebel di Kabupaten Jepara memerlukan perhatian, khususnya kinerja pemasaran berbasis gender diversity. UKM mebel di Jepara tidak hanya dipimpin oleh kaum pria, tetapi juga banyak dipimpin oleh wanita. Berdasarkan usahanya seorang wanita banyak yang berkembang baik, bahkan lebih maju dari pada usaha yang dipimpin seorang pria. Secara umum UKM mebel di Kabupaten Jepara pemasarannya berjalan secara natural yang belum ditopang oleh sumber daya manusia, inovasi produk, inovasi pemasaran, keunggulan bersaing, akses jaringan dan kinerja pemasaran yang baik. Kinerja pemasaran yang masih lemah dan organisasi belum dikelola oleh kaum pria maupun wanita dengan baik dan potensi gender diversity belum dimanfaatkan oleh UKM mebel di Kabupaten Jepara.

Gender (pemilik pria) tidak memiliki dampak yang signifikan terhadap kinerja perusahaan. Sebaliknya, jenis kelamin (pemilik wanita) memiliki dampak positif dan signifikan pada pertumbuhan bisnis dan kelangsungan hidup bisnis mereka. Meskipun hasil untuk pertumbuhan bisnis berbeda dari hasil untuk kinerja perusahaan dimana kepemilikan perempuan tidak memiliki dampak signifikan terhadap kinerja perusahaan, Pertumbuhan bisnis diukur dalam jangka waktu yang lebih panjang, menunjukkan bahwa lebih lama periode, wanita lebih baik dalam mengelola bisnis daripada pria berada dalam posisi yang sama.(Fitriya, 2014)

Fenomena seperti diatas sangat menarik untuk dikaji lebih mendalam tentang kinerja pemasaran berbasis gender diversity. Kemajuan kinerja pemasaran dalam menjalankan bisnis diperlukan inovasi produk untuk menghasilkan produk berkualitas. Inovasi pemasaran akan mendapatkan customer yang baik, keunggulan bersaing menjadi tolak ukur perusahaan di pasar global dan mengembangkan pasar lebih luas.

Kinerja pemasaran yang baik, merupakan komitmen para UKM mebel untuk memenuhi kebutuhan pelanggan. Inovasi pemasaran, inovasi produk, keunggulan bersaing dan akses berperan untuk meningkatkan kinerja pemasaran diperkuat keterlibatan gender diversity.

Beberapa faktor yang mempengaruhi kinerja pemasaran yaitu inovasi produk, inovasi pemasaran, keunggulan bersaing dan akses jaringan. Perhatian UKM mebel terhadap kinerja pemasaran yang didukung produk berkualitas, pasar yang baik, dan keunggulan bersaing untuk membangun kepercayaan, hal ini tidak lepas dari peran gender diversity. Paradigma 
kinerja pemasaran berbasis gender diversity adalah untuk mengetahui sejauhmana peran gender diversity dalam proses bisnis.

Inovasi pemasaran juga merupakan upaya perusahaan dalam meningkatkan kinerja pemasaran, tetapi penelitian ada yang mengatakan bahwa hubungan antara inovasi pemasaran dan kinerja pemasaran tidak signifikan (Lee, 2016). Inovasi pemasaran juga menunjukkan hasil tidak konsisten. Dengan pernyataan tersebut masih ada research gap, maka diperlukan penelitian lebih lanjut mengenai kinerja pemasaran yang berbasis gender diversity.

Untuk menyelesaikan masalah diajukan sebuah konsep baru untuk memecahkan fenomena bisnis antara gender pria dan gender wanita terhadap kinerja pemasaran. maka peneliti mengajukan sebuah konsep "Kinerja Pemasaran Berbasis Gender Diversity"

Tujuan Penelitian ini adalah untuk mengetahui peran keberhasilan gender diversity dalam kinerja pemasaran UKM mebel di Kabupaten Jepara.

\section{MASALAH PENELITIAN}

Rumusan masalah dalam penelitian ini adalah apakah UKM Mebel di Kabupaten Jepara yang dipimpin kaum pria akan lebih sukses dalam kinerja pemasaran atau sebaliknya wanita akan unggul dan lebih berhasil di dalam kinerja pemasaran.

\section{KAJIAN TEORITIS}

\section{Perbedaan Jenis Kelamin (Gender Diversity)}

Di Camerun banyak kewirausahaan wanita berkembang diantaranya sektor UKM yang dapat berkontribusi terhadap pertumbuhan ekonomi dengan mengurangi pengangguran terutama bagi wanita, menghasilkan pendapatan untuk pemerintah dan meningkatkan keterampilan sumber daya manusia (Efogo danTimba, 2014).

Di Nigeria, wanita memainkan peran penting dalam kinerja pasar, kualitas kelembagaan, stabilitas ekonomi makro dan gender adalah faktor penting penentu kinerja pasar di pasar saham Nigeria. Tetapi hasilnya adalah kinerja terbaik ditunjukkan wanita dalam pengelolaan Bursa Efek (Adetula dan Ojo, 2015)

Keragaman gender sering dioperasionalkan dan didefinisikan sangat dalam yang berakar pada sifat biologis yang diasumsikan (khususnya ketrampilan pria/wanita). Asumsi yang sangat sederhana ini bahwa pria dan wanita berperilaku berbeda tidak mempertimbangkan teori gender dan keragaman, tetapi hanya mereproduksi perilaku gender. Dalam kemasyarakatan, organisasi, kelompok dan individu gender mempunyai dampak 
dalam posisi manajemen puncak (Klarbach, 2014). Keragaman Gender usaha kecil dan menengah (UKM) milik sektor perusahaan berbasis teknologi

Di Spanyol menunjukkan bahwa keragaman jenis kelamin secara positif hubungan antara kemampuan kombinasi pengetahuan dan kinerja inovasi, diantaranya yaitu cara-cara untuk berkontribusi agar lebih setara distribusi gender dan manfaat keragaman gender dalam posisi manajemen puncak (Arroyo, 2014). Kepemimpinan dalam konteks campuran gender mendorong perspektif wanita sebagai sumber daya berharga dalam UKM (Kengne, 2015). Golden (2014) menunjukkan bahwa keragaman gender bermanfaat bagi kinerja. Hubungan antara keragaman gender dan kinerja perusahaan membantu untuk memperkuat nilai-nilai tata kelola perusahaan melalui hubungan keragaman gender, yang mempengaruhi kinerja perusahaan di berbagai industri dan dibeberapa industri tertentu.

\section{Kinerja Pemasaran}

Denton (2009 berpendapat bahwa perusahaan yang memiliki keunggulan bersaing akan dapat mencapai kinerja pemasaran yang tinggi/superioritas karena kinerja pemasaran superior dapat dicapai dengan baik melalui keunggulan bersaing, Ilyas (2011 : 1233) kinerja pemasaran yang unggul akan dicapai melalui tiga keuntungan, yaitu keunggulan komparatif, keunggulan bersaing dan keuntungan kooperatif. Kinerja yang buruk dari pemasaran cenderung disebabkan oleh persaingan yang rendah. Hal ini ditunjukkan oleh penelitian yang dilakukan oleh Ratnaningsih dan Wiguna (2010) yang menunjukkan bahwa unsur-unsur keunggulan bersaing seperti kecepatan pengiriman, kualitas, tingkat harga, teknologi, dan jaringan tetap memberikan manfaat rendah sementara biaya yang dibutuhkan tinggi.

Kinerja pemasaran masih relatif rendah, terutama pada unsur-unsur dalam meningkatkan kepuasan pelanggan yang dapat meningkatkan loyalitas pelanggan. Peneliti pemasaran untuk menyelidiki bagaimana tujuan organisasi dapat diterjemahkan ke dalam tujuan pemasaran dan indikator kinerja pemasaran yang memadai. Penelitian masalah ini menjadi tantangan akademis yang semakin penting di masa yang akan datang.

Agar dapat mengevaluasi kinerja, tujuan yang dipilih idealnya harus disajikan kembali dalam bentuk operasional dan terukur. Hal ini dimungkinkan untuk tujuan yang nyata. Kinerja pemasaran didefinisikan seberapa efektif dan efisien upaya pemasaran berkontribusi pada penciptaan nilai-nilai dan kemampuan untuk membuat mereka dalam jangka panjang. Masa sekarang model untuk evaluasi kinerja pemasaran yang secara eksplisit didasarkan pada ide-ide dan pandangan relasional seni tersedia (Toepoel, 2008). 
Menurut Daston dan Mangles (1997) inovasi memiliki peran langsung dalam mengembangkan produk baru dan mengembangkan perusahaan industri. Studi ini menunjukkan harapan terhadap inovasi produktif baru membantu menembus pasar yang ada. Inovasi dibutuhkan setiap perusahaan untuk berhasil dan bertahan hidup (Jimnez dan SanzValle, 2011) dan memperoleh keunggulan bersaing (Standing dan Kinniti, 2011), global (Amara dan Landry, 2005). Departemen perdagangan dan perindustrian UK mengasumsikan inovasi merupakan proses mengubah peluang menjadi ide-ide baru dan menempatkan ide ke banyak praktek.

Kinerja organisasi dalam lingkungan bisnis jangka panjang harus mengetahui dan membangun hubungan yang saling menguntungkan antara perusahaan dengan pelanggannya. Strategi marketing mix antara penawaran dan permintaan berperan dengan kinerja pemasaran (Payangan at al., 2017). Agar manajemen efektif harus ada akuntabiltas terhadap setiap segmen di seluruh bagian proses pemasaran. Kemampuan dan pengukuran untuk proses kinerja pemasaran berdasarkan segmen sangat penting untuk strategi pemasaran (Dempster dan Lee, 2015). Berbisnis harus menempatkan konsumen sebagai raja dalam organisasi berarti menunjukkan bahwa perusahaan ingin memberi nilai lebih kepada pelanggan dengan harapan memperoleh keunggulan bersaing jangka panjang, sehingga dapat memberikan keuntungan yang superior (Limakrisna dan Yoserizal, 2016). Kinerja pemasaran merupakan hal yang harus diimplementasikan dalam proses bisnis yang merupakan bagian dari kinerja organisasi. Seluruh proses strategi perusahaan selalu diarahkan untuk menghasilkan kinerja pemasaran yaitu volume penjualan, market share, pertumbuhan penjualan dan kinerja pemasaran sebagai usaha pengukuran tingkat kinerja meliputi omzet penjualan, jumlah pembeli, keuntungan dan pertumbuhan penjualan ( Ferdinand, 2006).

Menurut Pribadi dan Kanai (2011) kinerja pemasaran adalah sebuah prestasi yang diperoleh perusahaan dari kegiatan pemasaran yang dilakukan. Kinerja pemasaran lebih tepat diukur melalui perspektif pelanggan yaitu kepuasan pelanggan, kemampuan profit pelanggan, dan akuisisi pelanggan baru (Abdul, 2010). Kinerja pemasaran perusahaan masih relatif rendah, terutama pada unsur-unsur dalam meningkatkan kepuasan pelanggan yang dapat meningkatkan loyalitas pelanggan. Saat ini, ada model untuk evaluasi kinerja seni pemasaran yang secara eksplisit didasarkan pada kedua ide-ide dan pandangan relasional seni yang tersedia (Toepoel, 2008). Kinerja pemasaran dan barometer perusahaan untuk sukses, pengembangan kinerja pemasaaran, seluruh kreativitas nilai dan kontrol faktor internal berpengaruh terhadap pembisnis (Suwandari, 2017). 


\section{Inovasi Produk}

Karakteristik organisasi perusahaan dapat mempengaruhi inovasi produk (Kok dan Biemans 2009), dan dapat bergantung pada industri (Vega-Jurado et al., 2008). Hubungan antara kontekstual variabel dan inovasi produk pada umumnya terbatas. (Jajja at.al., 2014). Inovasi produk dari berbagai perspektif konsumen, bisnis, dan pasar, penyediaan produk baru yang lebih efektif bagi konsumen (Benner dan Tushman 2003; Zheng, Yim, dan Tse, 2005); dari perspektif bisnis, inovasi produk mengacu pada kebaruan yang lebih besar dari pasar, teknologi, dan metode produksi terkait produk; dari perspektif pasa dan inovasi produk. David (2005) percaya bahwa inovasi produk adalah perubahan inkremental dan peningkatan dalam produk, layanan, dan proses. Ini termasuk respon kreatif dan solusi untuk memenuhi kebutuhan dan harapan konsumen dan pasar, kekuatan pendorong keadaan bisnis, dan kebutuhan strategi organisasi.

\section{Inovasi Pemasaran}

Daston dan Mangles (1997) menyatakan bahwa inovasi memiliki peran langsung dalam mengembangkan produk baru dan mengembangkan perusahaan industri. Studi ini menunjukkan pelanggan bahwa harapan terhadap inovasi produktif baru membantu menembus pasar yang ada. Selanjutnya, ia mengklaim bahwa perusahaan industri harus terus mengembangkan kualitas, mengurangi biaya, dan meningkatkan efektivitas kerja, yang dikonfirmasi oleh Kholi dan Jaworski (1999). Dari penelitian lain yang berhubungan dengan topik penting adalah Nasri Aldeen dan Mansouri Zein, Murad (2010) dan Sarhan (2005).

\section{Keunggulan Bersaing}

Keunggulan bersaing mencapai keunggulan melalui nilai pelanggan superior menciptakan strategi yang kompetitif untuk mencapai keuntungan dan pertumbuhan bisnis. Konsep keunggulan kompetitif berasal dari strategi generik Porter. Strategi perusahaan diarahkan untuk memenangkan persaingan di pasar sasaran. Sebuah kompetisi akan menang jika mampu menciptakan strategi bisnis melalui keunggulan kompetitif (Suryaningsih dan Abdul, 2010). Keunggulan kompetitif sangat penting bagi pengembangan dan kelangsungan bisnis di pasar (Awuah dan Gebrekidan, 2008). Pelanggan adalah inti dari bisnis (Alharthi, 2012). Oleh karena itu, tingkat respons yang tinggi menuntut perusahaan untuk mengidentifikasi dan memenuhi keinginan pelanggan, dan akibatnya nilai pelanggan yang dirasakan akan membawa persaingan keuntungan bagi perusahaan. Kepuasan pelanggan dapat 
dicapai melalui kualitas yang tinggi, inovasi produk dan inovasi layanan. Dimensi ini menghasilkan kesetiaan (Hill dan Jones, 2009).

Dalam lingkungan yang kompetitif, strategi memaksimalkan pendapatan dan membutuhkan peningkatan pangsa pasar yang baik, meningkatkan produktivitas dan memperkenalkan produk terkait dengan keuntungan (Gonzalez-Perez dan Gutierrez-Viana, 2012). Terlepas dari kenyataan bahwa sangat sulit untuk mengidentifikasi ketentuan yang kuat secara konseptual definisi untuk keunggulan kompetitif dalam literatur, Sigalas et al. (2013) menggabungkan semua karakteristik laten dari konsep keunggulan bersaing dan memisahkan keunggulan kompetitif dari sumbernya dan dari konsep kinerja yang unggul. Khususnya, Sigalas et al. (2013) menyebutkan bahwa keunggulan kompetitif adalah rata-rata industri di atas eksploitasi peluang pasar dan netralisasi ancaman persaingan. Lebih jauh, keunggulan kompetitif tidak setara dengan superior kinerja, yang menurut Amit dan Schoemaker (1993) adalah rata-rata di atas kinerja keuangan dan operasional. Suatu perusahaan dikatakan memiliki keunggulan kompetitif ketika perusahaan melakukan sesuatu yang lebih baik daripada miliknya pesaing, atau mampu melakukan sesuatu yang tidak dapat dilakukan oleh industri lain yang sama pasar (Porter 1998). Kemampuan infrastruktur sebagai sumber keunggulan kompetitif (Bhatt et al., 2010; Chang dan Chuang, 2011; Jee-Hae et al,. 2012). Paradigma yang berubah dari keunggulan kompetitif di era yang berbeda melengkapi satu sama lain dengan kaitannya dengan diferensiasi organisasi sumber daya sebagai sumber keunggulan kompetitif. Keunggulan kompetitif diperoleh dengan memanfaatkan perpaduan unik dari aktivitas, aset, atribut, kondisi pasar, dan hubungan yang membedakan organisasi dari para pesaingnya (Ling, 2014).

\section{Akses Jaringan}

Pengertian akses adalah kemampuan untuk mendapatkan manfaat dan sesuatu atau hak untuk memperoleh kekuasan (Ribot dan Peluso, 2003). Definisi akses adalah hak untuk memasuki, memakai dan memanfaatkan kawasan atau zona-zona tertentu (Schlager dan Ostrom, 1993). Akses berarti jalan atau izin masuk dari suatu tempat/wilayah baik yang dapat dilihat atau tidak dimana kita dapat berhubungan dengan sumber daya yang ada di dalam wilayah tersebut sesuai dengan izin yang dimiliki. Manajemen jaringan ditujukan untuk mengurangi peluang kegagalan, terutama melalui perencanaan dan pengendalian. Pemantauan jaringan setiap hari untuk memastikan bahwa jaringan tetap pada tingkat operasi yang 
diinginkan. Pengendalian jaringan meliputi prosedur-prosedur seperti deteksi kegagalan, isolasi kegagalan dan pemulihan jaringan.

Kegagalan adalah tiap kesalahan dalam data yang dikomunikasikan seperti sambungan komunikasi yang tidak berfungsi atau kondisi lain yang membuat data tidak tiba secara tepat. Bisnis network marketing atau pemasaran jaringan ternyata memiliki banyak keunggulan besar. Bahkan penulis buku terkenal "Rich Dad Poor Dad", Robert T. Kiyosaki, meruntuhkan prasangka banyak orang selama ini yang menganggap bisnis pemasaran adalah bisnis bersistem piramida yang hanya menguntungkan orang yang berada di puncak bisnis tersebut. Berdasarkan pengalaman dan pengamatan Kiyosaki terhadap pebisnis-pebisnis sukses, faktor karakter dan kecerdasan emosional adalah faktor utama kesuksesan mereka. Begitu mereka memiliki karakter sebagai orang sukses, maka kesuksesan bisnis datang dengan sendirinya. Karena itulah, Kiyosaki menyarankan orang untuk memasuki bisnis pemasaran jaringan yang menyediakan pendidikan yang bagus untuk mengembangkan kecerdasan emosional.

\section{Pengembangan Hipotesis}

Berdasarkan pembahasan diatas dan penelitian menunjukkan inovasi produk, inovasi pemasaran, keunggulan bersaing, akses jaringan berpengaruh pada kinerja pemasaran, maka dirumuskan hipotesis sebagai berikut:

H1 : Inovasi produk berpengaruh positif dan signifikan terhadap kinerja pemasaran

$\mathrm{H} 2$ : Inovasi pemasaran berpengaruh positif dan signifikan terhadap kinerja pemasaran

H3 : Keunggulan bersaing berpengaruh positif dan signifikan terhadap kinerja pemasaran

H4 : Akses jaringan berpengaruh positif dan signifikan terhadap kinerja pemasaran

\section{Model Penelitian}

Kontruk variabel independen dengan variabel dependen yaitu pengaruh inovasi produk, inovasi pemasaran, keunggulan bersaing dan akses jaringan. terhadap kinerja pemasaran, dibandingkan antara pria dan wanita dapat dilihat pada gambar 1. 
Gambar 1. Konstruk variabel independen dengan variabel dependen

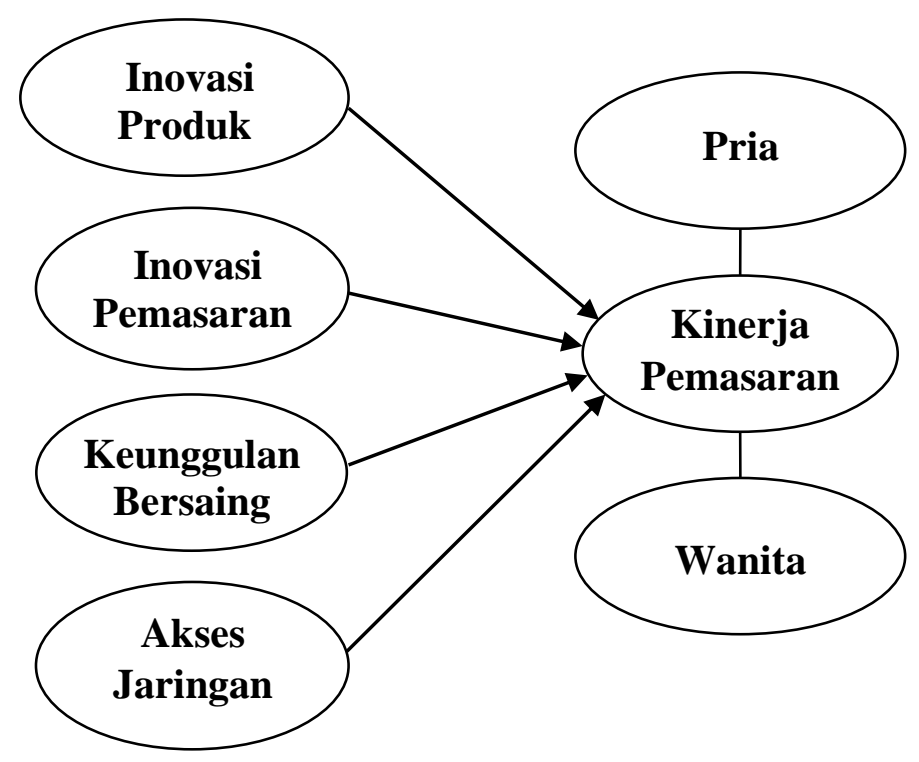

\section{METODOLOGI}

Sampel, populasi yang digunakan dalam penelitian adalah pimpinan dan manajer UKM mebel di Kabupaten Jepara yang berjumlah 460 perusahaan yang menjadi anggota HIMKI. Peneliti mengambil sampel berjumlah 100 sampel yang terdiri dari 50 sampel pria dan sampel wanita pimpinan atau manajer 50 UKM mebel yang menjadi anggota HIMKI Kabupaten Jepara. Teknik pengambilan sampel yang digunakan dalam penelitian ini adalah purposive sampling, dimana masing-masing komponen yang menjadi populasi ditentukan dengan kriteria tertentu untuk diambil sebagai sampel.

Pengumpulan data, data yang diperoleh dalam penelitian ini didapat dengan cara mengisi kuesioner oleh responden, Respondennya dalam penelitian ini adalah pimpinan dan manajer UKM mebel yang terdaftar menjadi anggota HIMKI Kabupaten Jepara.

Sumber data, dalam penelitian ini, data primer yang diambil berupa data HIMKI di Kabupaten Jepara tahun 2018

Pengukuran dan definisi operasional variabel, agar memudahkan pemahaman terhadap metode penelitian ini, berikut disajikan sebuah variabel konstruk dan indikator, seperti tersaji pada tabel 3 berikut ini. 
Tabel 3.Variabel konstruk dan indikator penelitian

\begin{tabular}{lll}
\hline \multicolumn{1}{c}{ Variabel } & \multicolumn{1}{c}{ Indikator } & Skala linkert \\
\hline Kinerja Pemasaran & 1. Volume Penjualan & \\
(Limakrisna1 \& & 2. Pengembangan produk baru & $1-7$ \\
Yoserizal ,2016) & 3. Peningkatan pangsa pasar & \\
& 4. Pertumbuhan pelanggan & \\
Inovasi Produk & 1. Desain baru & $1-7$ \\
(Jajja at. al., 2014) & 2. Sesuai pangsa pasar & \\
& 3. Desain beda & $1-7$ \\
Inovasi Pemasaran (Al- & 4. Produk Unik & \\
Zyadaat, et. al.,2012). & 2. Kreativitas harga & \\
dan ( Lee. et. al.,2016) & 3. Kreativitas produk & $1-7$ \\
& 4. Tempat inovasi produk & \\
Keanggulan bersaing & 1. Superioritas citra produk & \\
(Laselewo, at. al. 2016) & 2. Superioritas daya tarik & \\
& 3. Superioritas emosi pelanggan & $1-7$ \\
Akses Jaringan & 4. Kualitas produk & \\
(Kiyosaki, 2005) & 1. Kepuasan pelanggan & \\
& 2. Inovasi pelayanan & \\
& 3. Cepat tanggap pasar & \\
& 4. Berbagi pengetahuan & \\
\hline
\end{tabular}

\section{Definisi operasional variabel}

Definisi operasional dari variabel yang digunakan dalam penelitian ini yaitu:

a. Kinerja pemasaran merupakan sebuah prestasi yang diperoleh UKM mebel dari kegiatan penjualan dan nilai volume penjualan.

b. Inovasi produk merupakan perubahan UKM mebel dalam peningkatan produk, layanan, dan proses untuk memenuhi kebutuhan dan harapan konsumen dan pasar, kekuatan pendorong keadaan bisnis, dan kebutuhan strategi organisasi.

c. Inovasi pemasaran merupakan kemampuan UKM mebel mengubah peluang menjadi ideide baru.

d. Keunggulan kompetitif merupakan usaha UKM mebel dalam bersaing mencapai keunggulan melalui nilai pelanggan superior menciptakan strategi yang kompetitif untuk mencapai keuntungan dan pertumbuhan bisnis.

e. Akses jaringan adalah kemampuan UKM mebel untuk mendapatkan manfaat dan sesuatu atau hak untuk memperoleh pasar, dan kekuasaan dalam meraih keinginan pelanggan. 


\section{Metode Analisis Data}

Data diolah dengan program SPSS 16.0 dengan uji reliabilitas, uji validitas, uji $\mathrm{F}$ seluruh sampel, uji F gendar pria dan uji F gender wanita. Dengan analisis regresi dengan Anova akan diketahui perbedaan gender pria dan gender wanita.

\section{Model Empiris}

Kontruk variabel dan pengaruh antar indikator variabel independen dengan variabel dependen yaitu pengaruh inovasi produk terhadap kinerja pemasaran, pengaruh inovasi pemasaran terhadap kinerja pemasaran, pengaruh keunggulan bersaing terhadap kinerja pemasaran, pengaruh akses jaringan pengaruh terhadap kinerja, dibandingkan antara gender pria dan gender wanita. Pengaruh antar variabel dan indikator masing-masing variabel dapat dilihat di gambar 1.

Gambar 1. Konstruk Variabel dan pengaruh antar Indikator Variabel Independen dengan

Dependen

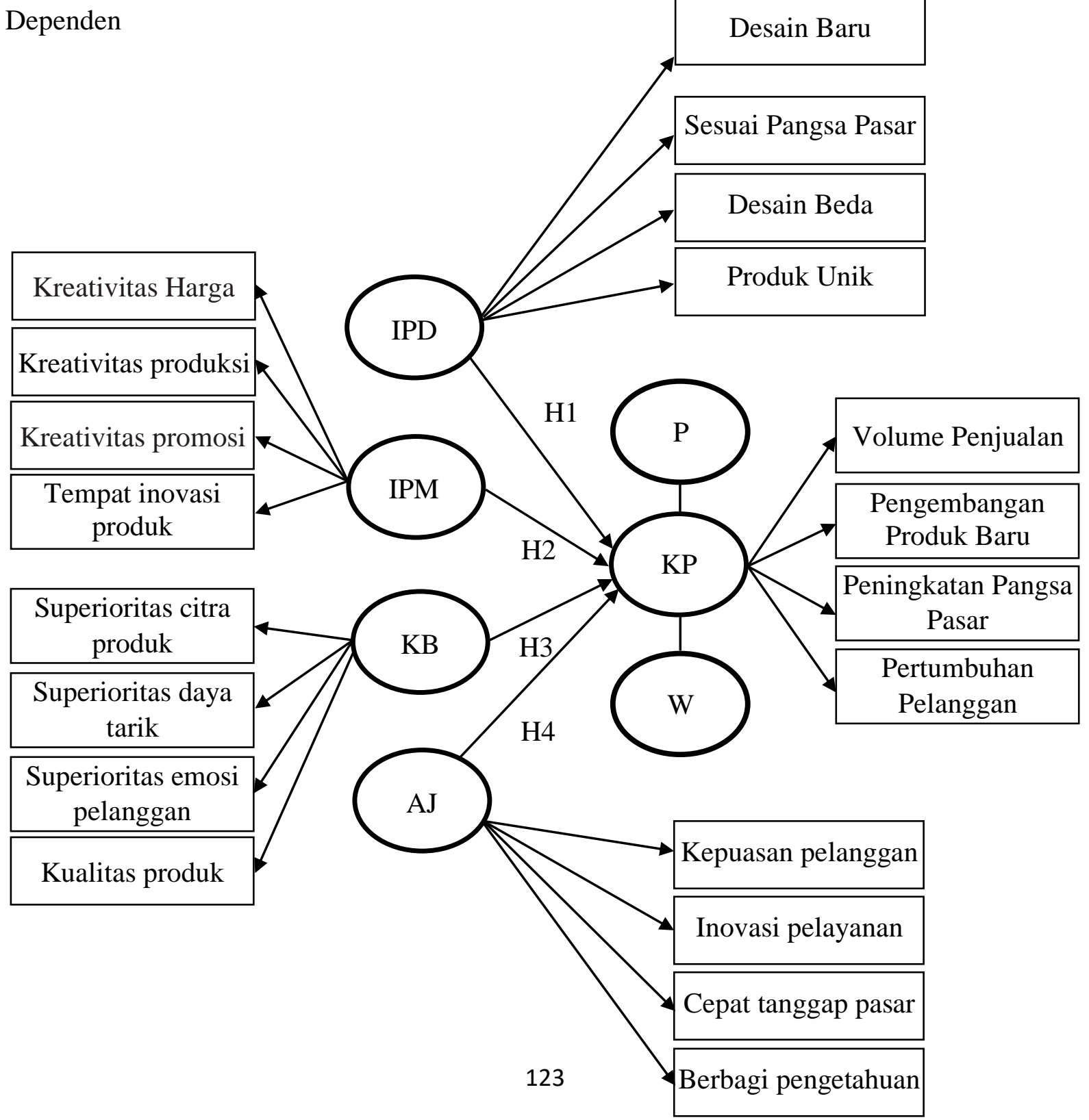


Keterangan:

IPD : Inovasi Produk

IPM : Inovasi Pemasaran

KB : Keunggulan Bersaing

AJ : Akses Jaringan

KP : Kinerja Pemasaran

P : Pria

W : Wanita

\section{PEMBAHASAN}

Kinerja pemasaran di UKM mebel Kabupaten Jepara secara simultan dipengaruhi oleh inovasi produk, inovasi pemasaran, keunggulan bersaing dan akses jaringan. Secara parsial masing-masing variabel independen berpengaruh positif dan signifikan terhadap kinerja pemasaran. Namun demikian berdasarkan gender deversity, gender pria dan wanita masingmasing mempunyai pengaruh yang berbeda. Sesuai studi empiris yang diolah data dengan SPSS 16.0 di hasilkan uji F pria dan uji F wanita di tabel 1 dan tabel 2 sebagai berikut:

Tabel 1 Uji F Pria

\begin{tabular}{lll|c|c|c|c}
\multicolumn{2}{c}{} & \multicolumn{2}{c}{ 1. ANOVA $^{\mathbf{a}}$} & & \\
Model & & $\begin{array}{c}\text { Sum of } \\
\text { Squares }\end{array}$ & Df & Mean Square & F & Sig. \\
\hline \multirow{2}{*}{1} & Regression & 241,313 & 4 & 60,328 & 58,753 &, $000^{\mathrm{b}}$ \\
\cline { 2 - 8 } & Residual & 46,207 & 45 & 1,027 & & \\
\cline { 2 - 8 } & Total & 287,520 & 49 & & & \\
\hline
\end{tabular}

a. Dependent Variable : Y

b. Predictors : (Constant), X4, X1, X2, X3

Tabel 2 Uji F Wanita

\begin{tabular}{lll|c|c|c|c}
\multicolumn{2}{c}{} & \multicolumn{3}{c}{ ANOVA $^{\mathbf{a}}$} & \\
Model & & $\begin{array}{c}\text { Sum of } \\
\text { Squares }\end{array}$ & Df & Mean Square & F & Sig. \\
\hline \multirow{2}{*}{1} & Regression & 310,474 & 4 & 77,618 & 80,247 &, $000^{\mathrm{b}}$ \\
\cline { 2 - 8 } & Residual & 43,526 & 45 &, 967 & & \\
\cline { 2 - 8 } & Total & 354,000 & 49 & & & \\
\hline
\end{tabular}

a. Dependent Variable : Y

b. Predictors : (Constant), X4, X1, X2, X3 
Berdasarkan hasil uji $\mathrm{F}$ bahwa gender pria mempunyai pengaruh sebesar 58,763 dan gender wanita mempunyai pengaruh sebesar 80,247

\section{KESIMPULAN}

Berdasarkan hasil penelitian ini bahwa inovasi produk, inavosi pemasaran, keunggulan bersaing, dan akses jaringan mempunyai peran penting dalam meningkatkan kinerja pemasaran. Studi empiris menunjukkan, berdasarkan perbedaan jenis kelamin masing-masing mempunyai pengaruh yang berbeda-beda. Jenis kelamin pria variabel inovasi produk, inovasi pemasaran, keunggulan bersaing, akses jaringan secara simultan mempunyai pengaruh terhadap kinerja pemasaran sebesar 58,763 dan jenis kelamin wanita variabel inovasi produk, inovasi pemasaran, keunggulan bersaing, akses jaringan secara simultan mempunyai pengaruh terhadap kinerja pemasaran sebesar 80,247. Hasil tersebut menunjukkan bahwa gender wanita lebih unggul dibanding gender pria hanya sebesar 58,763 berbanding gender wanita sebesar 80, 247 di bidang kinerja pemasaran. Hasil studi tersebut menunjukkan bahwa wanita dalam bidang pemasaran sangat berperan dalam meningkatkkan bisnis dibanding pria. Terbukti dengan penelitian terdahulu bahwa dikatakan wanita dalam kinerja pasar, kualitas kelembagaan, stabilitas ekonomi makro dan gender faktor penting di pasar, dan kinerja terbaik ditunjukkan wanita (Adetula dan Ojo, 2015).

Keterbatasan penelitian ini hanya menguji lima variabel; inovasi produk, inovasi pemasaran, keunggulan bersaing, akses jaringan dan kinerja pemasaran. Untuk penelitian mendatang perlu variabel yang mendukung variabel dependen. Peneliti mempunyai harapan bahwa variabel new customer sebagai pendukung variabel baru dalam penelitan berikutnya dan penelitian dilakukan dengan kluster gender diversity.

\section{DAFTAR PUSTAKA}

Adetula, D.T, Ayadi. M.F. dan F.A. Olusegon, 2015, Gender diversity in the governance of the Nigerian securities market, Corporate Governance, 15(5): 734-746

Al-Zyadaat. M.A., M.A. Saudi dan M.A. Al-Awamreh. 2012 The Relationship Between Innovation and Marketing Performance in Business Organizations: An Empirical Study on Industrial Organizations in the Industrial City of King Abdullah II. International Business and Management, 5(2): 76-84

Arroyo, R,Matilde, M.Ruit,J.Nez, dan M.M.F.Fuentes, 2014, Knowledge Combination Capability and Innovation: The Effects of Gender Diversity on Top Management Teams in Technology-Based Firms • J Bus Ethics, 7 (014): 135:503 
Bampo, Mauro, Ewing, T. Michael, Mather, R.Dineli, Stewart, David, Wallace, dan Mark, 2008. The Effects of the Social Structure of Digital Networks on Viral Marketing Performance. Information Systems Research,19(3): 273

Boorsma. M dan F. Chiaravallot, 2013. Arts Marketing Performance: An Artistic-Mission-Led Approach to Evaluation. The Journa Of Art Management, Law, And Society, 40: 297-317.

Chen. S.T. dan B.G. Chang, 2013. The effects of product innovation on product life cycle patterns in Taiwanese motors: views of consumer preferences. Journal of Business and Retail Management Research (JBRMR) 8(1)

Chuang. S.H., C. Liao dan S. Lin. 2013. Determinants of knowledge management with information technology support impact on firm performance. Inf Technol Manag, $14: 217-230$.

Dempster C. dan J. Lee, 2015. The Rise of the Platform Marketer. Performance Marketing with Google, Facebook, and Twitter, Plus the Latest High-Growth Digital Advertising Platforms. Published by John Wiley \& Sons, Inc., Hoboken, New Jersey. Published simultaneously in Canada.

Efogo, F.O dan Timba. G.T (2014), Female entrepreneurship and growth in Cameroon, African Journal of Economic and Management Studies,. 6(1); 107-119.

Elshaer. A. dan M. M. Augustyn. 2015. Quality paper Direct effects of quality management on competitive advantage. International Journal of Qualit \& Reliability Management, 33(9); 1286-1310

Ferdinand. A., 2014. Metode Penelitian Manajemen. Edisi 5. Badan Penerbit Universitas Diponegoro.

Fitriya, M. Idris dan A. Basyith,2014, The Gender Effect On Small Bussiness Enterprises Firm Performance Eviden From Indonesia, Indian Journal of Economics \& Business, Vol. 13, No. 1, (2014) : 21-39

Ghozali. I. dan Fuad 2014. Structural Equation Modeling Teori, Konsep dan Aplikasi dengan Program Lisrel Lisrel 9.10. Edisi 4. Badan Penerbit Universitas Diponegoro.

Golden. B, H. Parola dan .K. M. Ellis, 2014, Performance effects of top management team gender diversity during the merger and acquisition, Emerald Group Publishing Limited, 53(1): 57-74.

Hsu. T. T., 2016. The Relationships Of Strategic Orientation, Breakthrough Innovation, And Product Performance. ISPIM Innovation Summit Moving the Innovation Horizon, 4-7.

Jajja. M. S.S., S.. S.H. A.Brah dan V. R. Kannan, 2014. An examination of product innovation and buyer-supplier relationship in Pakistani firms. International Journal of Productivity and Performance Management, 63(8); 1031-1045 
Kengne. B.D.S, 2016. Mixed-gender ownership and fnancial performance of SMEs in South Africa A multidisciplinary analysis, JEL classifcation - C23, C25, D21, G34, L2

Klarbach, 2014, Gender in top management research Towards a comprehensive research framework, Emerald Group Publishing Limited, 37(6). 538-552

Lasalewo. T, N.A. Masruroh dan Subagyo, 2016. The Effect of Competitive Advantage and Human Advantage on Industrial Competitive Strategy (Case Study: SMIs in Gorontalo Province). Journal of Indonesian Economy and 31(3); 307 - 324

Lee. K, J. Yoo3, M. Choi1, H. Zo, Andrew. P dan. Ciganek. 2016. Does External Knowledge Sourcing Enhance Market Performance? Evidence from the Korean Manufacturing Industry.PLOS ONE : 10.1371

Limakrisna. N., dan S. Yoserizal. 2016. Determinants Of MarketingPerformance: Empirical Study At National Commercial Bank in Jakarta Indonesia. Limakrisna and Yoserizal SpringerPlus. 5:1693

Nuryakin dan B. B. Retnawati. 2016. Using Technological Relational Capabilities to Investigate Marketing Perfomance In International Wooden Market. Information, 19 (7); .2555-2563.

Payangan O.R., R. Sahbuddin, dan A.S. Girikallo, 2017. Mediation Effect of Marketing Mix Strategy on Supply and Demand Towards Marketing Performance. Journal of Environmental Management and Tourism.8 (1); 17-.21

Petpairote. W. dan N. Chancharat, 2015, The Effects of Women on the Board on the Firm Performance of Thai Listed Companies, Summer, 1 (11).

Pribadi J dan J. Kanai, 2011. Measurement marketing performance in banking industry. Journal on Management and Business, UTM Malaysia.

Ratnaningsih A, dan S. Wiguna, 2010. Indonesia banking industry competitive: effort for achieving competitive advantage. Indonesia Econ Bus J 10 (5):98-107.

Suwandari. L.,Y.Suryana., dan Y. Wirasasmita. 2017. Marketing Performance Of Batik Tulis Based Of Entrepreneurship Orientation In Daerah Istimewa Yogyakarta SME's.. Academy of Strategic Management Journal, 16 (3).

Suryaningsih E dan J. Abdul, 2010. The indicator of competitive advantage for banking industries. Int J Eco Manag 23 (10):5-9

Tuan N., N. Nhan, P. Giang, dan N. Ngoc. 2016. The Effects of Innovation on Firm Performance of Supporting Industries in Hanoi - Vietnam. Journal of Industrial Engineering and Management, 9 (2): 413-431.

Zhong. H. 2013. Organizational Slack and the Marketing Performance of Information Technology Firms. International Journal of Innovation, Management and Technology, $4(2)$ 